\title{
Robert Lassalle-Klein
}

Blood and Ink: Ignacio Ellacuría, Jon Sobrino, and the Jesuit Martyrs of the University of Central America, with a foreword by Jon Sobrino. Maryknoll: Orbis Books, 2014.

Pp. 376, xiii. $\mathrm{Pb}, \$ 34$.

This book seeks to probe the complex background and continuing relevance of the brutal assassinations of six Jesuit priests, as well as a lay co-worker and her daughter at the Jesuit-run University of Central America in El Salvador ("UCA") twenty-five years ago. This event changed the political landscape of both that war-torn country and the United States. It also shaped, for good and for ill, traumatically and creatively, the course of liberation theology: both in the loss of some of its most creative exponents, and in the work of those, like Jon Sobrino, who carried on in its wake. The book's length and scope at times overwhelms the organizational capacity of its framework, and some argumentative strands are more successful than others, but it serves as an invaluable starting point for anyone seeking to understand this history and its continuing relevance.

The book has no one overarching organizing principle beyond the deictic: pay attention; while each of the volume's three parts is centered on a more specific aim or thesis. The first part traces the history of El Salvador through its brutal civil war and associated atrocities. Lassalle-Klein pays particular attention to the role of the Jesuits and of their university in this story, elaborating the transformation of UCA in response to the Medellín documents and the Jesuit commitment to "the service of faith, of which the promotion of justice is an absolute requirement" (Documents of the $37^{\text {st }}$ and $32^{\text {nd }}$ General Congregation of the Society of Jesus [St. Louis, Miss.: Institute of Jesuit Sources, 1977], 411). He focuses on two decisive points in this metamorphosis: a three-day "retreat" of the members of the (then) vice-province of Central America in 1969, and the three-year tenure of Oscar Romero as archbishop of San Salvador (1977-80). Perhaps the most original and compelling part of the book is Lassalle-Klein's careful, meticulously researched description of the former, pivotal moment. He shows how the retreat's leaders (among them Ignacio Ellacuría, one of those slain in 1989) used the Spiritual Exercises to forge a framework for communal discernment. This shift led to substantive (and costly) changes to all of the vice-province's institutions, aligning them with Medellín's call for a preferential option for the poor. In the first of two separate treatments of the slain archbishop, Lassalle-Klein rightly points to Romero's influence on the UCA, arguing that Romero taught the university to turn its efforts more fully to listening to and empowering the poor (and less on trying to form or influence the country's economic, military, and political elites) — albeit in ways appropriate 
to a university, rather than an archdiocese. Much of this story has been told elsewhere, but Lassalle-Klein deftly brings the different accounts together in a highly readable narrative.

The last two parts focus on the philosophy and theology of Ellacuría (albeit in conjunction with Sobrino's Christology in the final section). The second part analyzes the principal influences on Ellacuría's thought - Ignatian spirituality, the philosophy of Xavier Zubiri, the theology of Karl Rahner and the witness of Oscar Romero. The final part constructs a theology from Ellacuría's fundamental theology and Sobrino's Christology. While Lassalle-Klein gives varying statements of these sections' overall aim, two articulations recur frequently: demonstrating that the philosophy and theology of Ellacuría (augmented by Sobrino) provide a "window on the joy and hope of their [i.e. the martyrs'] encounter with the Mystery of God dwelling in the heart of the historical reality of El Salvador" (340) and forms "what may be the most fully developed contextual theology since Vatican II" $(287,340)$. This is an ambitious agenda, and in the end the book approaches its goal, without fully attaining it.

In Lassalle-Klein's reading, the Spiritual Exercises imparted to Ellacuría an emphasis on history (more precisely, on "historical reality") as the proper object of philosophy and theology, and a theology of signs connected to Ignatius's teachings on discernment. Read in conjunction with the earlier discussion of Ellacuría's lectures during the 1969 retreat, this assessment is persuasive and enlightening. Lassalle-Klein follows with an analysis of how Ellacuría was influenced by his philosophical mentor and later collaborator, Xavier Zubiri. Some of these sections are heavy going, as Lasalle-Klein attempts the near-impossible task of providing concise summaries of Husserlian phenomenology. In this chapter and elsewhere, he makes the somewhat puzzling claim that Zubiri and Ellacuría offer an account of human knowing that correlates positively with modern neuroscience. This claim does not contribute significantly to his argument, since the requisite elaboration and justification require a far deeper engagement with the science itself and the extensive philosophical literature reflecting thereon. That said, Lassalle-Klein makes a strong case for the centrality of Zubiri's philosophy in Ellacuría's thought and provides a workable introduction to the philosophical terminology and argumentation fundamental to Ellacuría's philosophy and theology.

Least successful, in my judgment, is Lassalle-Klein's treatment of Karl Rahner. As Lassalle-Klein himself acknowledges, Rahner takes categories of meaning and being to be fundamental for philosophy and philosophical theology. This approach was explicitly and emphatically rejected both by Zubiri and by Ellacuría, for whom reality (historical reality for the latter) play an analogous role. Thus, the chapter's thesis that Ellacuría uses Zubirian concepts "to 
build upon and extend elements of Rahner's fundamental theology" (254) cannot but strike one a priori as at best counterintuitive, and at worst unredeemable. Lassalle-Klein's presentation does not overcome this initial suspicion. Perhaps he is in fact aware of this, as evidenced by the variety of verbs refining the relationship between the two Jesuits' thought: "builds on," "echoes," "mimics," "reframes," "clarifies," and "mimics [...] while shifting its philosophical underpinnings" $(187,265,274,278)$. While this constellation of verbs complicates - or even retracts - the chapter's thesis, taken together they also make it very difficult finally to decide what the relationship is. Moreover, Lassalle-Klein's presentation of Rahner's fundamental theology needs tightening (avoiding, for instance, translating the Rahnerian Vorgriff of Being as a "preapprehension" of Being, which, as Philip Endean and others have taught us, is quite misleading; or relying less on the short entries that Rahner co-authored with Herbert Vorgrimmler for their Kleines theologisches Wörterbuch).

Lassalle-Klein's treatment of Archbishop Romero's influence is more compelling, although not without its puzzles. He argues that Romero "taught [Ellacuría] to love the common people of El Salvador, to trust them, to see Christ in them, and to discover his prophetic vocation to take this crucified people down from the cross" (289). This seems eminently reasonable, but sometimes Lassalle-Klein emphasizes the point so strongly that one wonders how to interpret what Ellacuría was doing prior to 1977. On the last point, for example, do not Ellacuría's passionate presentations in the 1969 province retreat (ably presented earlier in the book), evince someone who has found a prophetic vocation - not to mention his sarcastic 1976 editorial about the government's abandonment of an agrarian reform proposal ("Aye, Aye! My Capital!")?

In sum, the book is rich and complex, ambitious in many different lines of argument-some more successful than others. Whole monographs have been written on particular features of this history, in particular on the life and thought of Ignacio Ellacuría. Considering only English-language texts, one thinks of Tommie Sue Montgomery's Revolution in El Salvador (Boulder: Westview, 1982), Theresa Whitfield's masterful story of the UCA martyrs, Paying the Price (Philadelphia: Temple University Press, 1994), Charles Beirne's Jesuit Education and Social Change in El Salvador (New York: Garland Press, 1996) as well as books by Kevin Burke and Michael Lee on Ellacuría's philosophy and theology: The Ground Beneath the Cross (Washington, D.c.: Georgetown University Press, 2000) and Bearing the Weight of Salvation (New York: Crossroad, 2009) respectively. While the present volume does not significantly advance this scholarship, it has the virtue of bringing together material from diverse sources (some available only in Spanish) and familiarizing the reader 
with the broad and variegated context for the events of the early morning hours of November 16, 1989. For this, the author deserves our gratitude.

\author{
J. Matthew Ashley \\ University of Notre Dame \\ ashley.2@nd.edu \\ DOI $10.1163 / 22141332-00202007-19$
}

